\title{
Combination effect of acetic acid and citric acid on calcium and phosphorus extraction from shank bone
}

\author{
Dong Chung Kim ${ }^{1}$ Sun Im Won ${ }^{2}$ Man-Jin $\operatorname{In}^{2}$ (D)
}

\section{초산과 구연산의 조합이 사골로부터 칼슘과 인의 용출에 미치는 영향}

\author{
김동청 ${ }^{1} \cdot$ 원선임 $^{2} \cdot$ 인 만진 $^{2}$
}

Received: 30 September 2016 / Accepted: 24 October 2016 / Published Online: 31 March 2017

(C) The Korean Society for Applied Biological Chemistry 2017

\begin{abstract}
This study was conducted to investigate the effect of acetic acid and citric acid treatments on amount and content ratio of calcium $(\mathrm{Ca})$ and phosphorus $(\mathrm{P})$ which were extracted from beef shank bones. The amount of $\mathrm{Ca}$ in shank bone extracts significantly increased with increasing citric acid and acetic acid concentration, whereas the amount of $\mathrm{P}$ increased with only adding citric acid to extraction media. In the case of combined treatment with $0.2 \%$ acetic acid and $0.1 \%$ citric acid, the amounts of $\mathrm{Ca}$ and $\mathrm{P}$ increased to 30 and $400 \%$, respectively and $\mathrm{Ca}$ and $\mathrm{P}$ ratio were drastically improved from 7.53 to 1.85 compared with treatment of $0.2 \%$ acetic acid. The sensory score of shank bone extract prepared with $0.2 \%$ acetic acid and $0.1 \%$ citric acid treatment showed the highest values in taste and overall acceptability among the tested shank bone extracts.
\end{abstract}

Keywords Acetic acid - Citric acid - Extraction - Shank bone

Man-Jin In $(\bowtie)$

E-mail: manjin@chungwoon.ac.kr

${ }^{1}$ Department of Integrated Materials Engineering, Chungwoon University, Incheon 22100, Republic of Korea

${ }^{2}$ Department of Human Nutrition and Food Science, Chungwoon University, Hongseong 32244, Republic of Korea

This is an Open Access article distributed under the terms of the Creative Commons Attribution Non-Commercial License (http://creativecommons. org/licenses/by-nc/3.0/) which permits unrestricted non-commercial use, distribution, and reproduction in any medium, provided the original work is properly cited.

\section{서 론}

우리나라는 전통적으로 사골, 꼬리, 잡뼈 등을 장시간 가열하여 수용성 맛성분을 용출시킨 액을 탕 요리에 또는 이차적으로 국 물 음식의 기본재료인 육수로 사용하여 왔다. 특히 사골을 주 원료로 이용하여 제조하는 곰탕은 우리나라 사람에게 부족되기 쉬운 칼슘뿐만 아니라 인과 마그네슘 등의 무기질 그리고 아미 노산 공급원으로 널리 이용되고 있다(Park과 Lee 1982; Seol과 Jang 1990). 사골곰탕 이외에 백김치(Park 등, 2003), 비빔밥 (Yoon 등, 2009), 냉장 즉석밥(Cho 등, 2014) 등의 분야에서도 사골 육수를 이용하는 연구가 보고되어 있다. 이와 같이 다양 한 식품으로 용도가 확장되는 사골 추출물에 대하여 영양성분 의 충분한 용출을 위하여는 12 시간 이상의 가열이 필요하다는 연구(Kim 2006), 한우의 사골 부위, 숙성도 그리고 추출횟수에 따른 특성(Kim 등, 1999; Kim 등, 2008), 추출조건에 따른 곰 탕의 젤화 여부와 아미노산 조성 변화에 의한 곰탕의 젤 생성 원인에 대한 연구(Kim 등, 2014) 등 영양성분의 용출량을 증가 시키고 품질을 향상시키기 위한 연구도 지속적으로 이루어지고 있다. 특히 칼슘 섭취의 부족은 뼈 질환, 골다공증, 골절, 순환 기계질환, 고혈압, 동맥경화 등 각종 성인병의 원인으로 작용하 므로(Karanja와 McCarron 1986) 사골 육수 제조 시 칼슘의 용 출량을 증가시키기 위한 연구도 보고되어 있다. Park과 Lee (1983)는 초산을 $0.1 \%$ 첨가하면, $\operatorname{Kim}$ (2002)은 곡물 식초와 구연산을 첨가하면 칼슘과 인의 용출이 유의적으로 증가하나 관 능적으로 다소 열악한 것으로 보고하였다. 또한 칼슘 함량을 증 가시키기 위하여 추출된 사골 곰탕에 물성 변화 없이 해조 칼 슘을 첨가하는 연구결과 $(\mathrm{Kim}$ 등, 2014)도 있다. 체내에서 칼슘 의 흡수는 칼슘과 인의 비율이 중요하므로 사골 육수의 영양학 적 가치를 향상시키기 위하여는 칼슘 흡수에 적합한 비율(칼슘 $/$ 인 $=2 \sim 1)$ 을 유지하면서 칼슘과 인의 함량을 증가시키는 것이 필 요하나 이에 관한 연구는 미흡한 실정이다. 
따라서 본 연구에서는 사골로부터 칼슘과 인의 가용화를 증 가시키는 효과가 보고된(Park과 Lee 1983; Kim 2002) 초산과 구연산을 이용하여 칼슘과 인의 용출량을 증가시킴과 동시에 칼 슘의 흡수에 효과적인 비율로 칼슘과 인의 함량을 조절하기 위 하여 초산과 구연산의 혼합효과를 조사하였다. 또한 얻어진 사 골 추출물의 관능적인 특성을 조사하였다.

\section{재료 및 방법}

\section{재료 및 사골 추출물 제조}

사골은 호주산으로 신성TNF (충남 홍성)로부터 제공받아 사용 하였다. 사골 추출물은 $\mathrm{Kim}$ 등의 방법(2014)을 이용하여 가압 추출로 제조하였다. $3 \sim 5 \mathrm{~cm}$ 크기로 절단하고 흐르는 물에 3시 간 동안 핏물을 제거한 사골 $250 \sim 300 \mathrm{~g}$ 을 칭량하고 3 배수의 추 출액를 가한 다음 autoclave를 사용하여 $121{ }^{\circ} \mathrm{C}$ 에서 5 시간 추출 한 후 4겹의 cheese cloth로 여과하여 사골 추출물을 제조하였다.

\section{칼슘과 인 함량 분석}

사골 추출물에 $10 \%$ trichloroacetic acid를 가하고 원심분리로 침전물을 제거한 다음 상등액의 칼슘 함량은 arsenazo III를 이 용한 발색법으로(Morgan 등, 1993), 인 함량은 몰리브덴 발색 법으로(Heinonen과 Lahti 1981) 각각 분석하였다. 칼슘과 인의 함량은 각각 뼈 $100 \mathrm{~g}$ 당 용출량으로 나타내었다.

\section{관능평가}

사골 추출물의 관능적인 특성은 $\mathrm{Kim}$ 등의 방법(2008)을 변형 하여 조사하였다. 사골 추출물을 $4 \mathrm{brix}$ 로 희석한 후 중탕으로 $60{ }^{\circ} \mathrm{C}$ 까지 가열하여 시료를 준비한 다음, 청운대학교 식품영양 학과 대학생 12 명을 대상으로 색, 향, 맛, 전체적인 기호도에 대 하여 5점 척도법으로 1회 평가하였다. 분석 결과는 Statistical Package for Social Science (SPSS Inc., Chicago, IL, USA, version 11.5)로 통계처리 하였으며 ANOVA를 이용하여 Duncan's multiple range test로 $5 \%$ 수준에서 각 시료간의 유의성을 검증 하였다(유의수준 $p<0.05$ ).

\section{결과 및 고찰}

구연산과 초산이 사골로부터 칼슘과 인의 용출에 미치는 특징 을 파악하기 위하여, 증류수에 초산 혹은 구연산을 $0 \sim 0.5 \%$ 첨 가하여 추출액으로 사용하였다(Fig. 1). 추출액에 구연산을 첨가 하는 경우 칼슘과 인의 용출량은 구연산의 농도에 비례하여 증 가하였으며, 증류수 추출액과 비교하면 $0.5 \%$ 농도에서 칼슘은 약 21 배 $(3.40 \rightarrow 72.27 \mathrm{mg})$, 인은 약 17 배 $(3.09 \rightarrow 51.75 \mathrm{mg})$ 용출 량이 증가하였다. 반면에 초산의 경우, 칼슘의 용출량은 초산 $0.1 \%$ 이상의 조건에서 초산 농도에 비례하여 크게 증가하였으나 인의 용출량은 미미하게 증가하였으며, 증류수 추출액과 비교하 면 $0.5 \%$ 농도에서 칼슘은 약 28 배 $(2.52 \rightarrow 70.76 \mathrm{mg})$, 인은 약 2 배 $(3.10 \rightarrow 7.43 \mathrm{mg})$ 용출량이 증가하였다. 또한 칼슘의 용출양 은 구연산과 초산이 매우 유사하였다. 즉, 구연산은 사골로부터 칼슘과 인을 유사하게 용출시키나, 초산은 인보다 칼슘을 선택
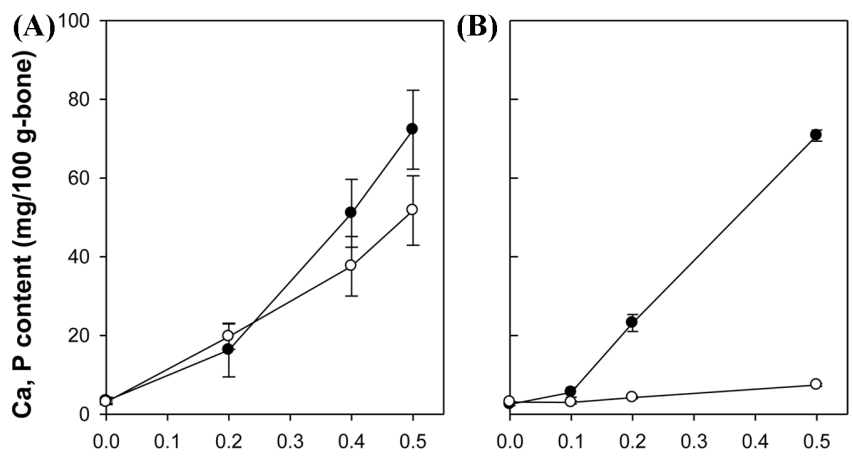

Citric acid concentration (\%)

Acetic acid concentration (\%)

Fig. 1 Effect of citric acid (panel A) and acetic acid (panel B) addition on calcium (closed circle) and phosphorus (open circle) extraction from beef shank bone

적으로 용출시키는 것으로 조사되었다. 인체에서 뼈와 치아를 이루는 중요한 무기질인 칼슘과 인은 비교적 안정되고 치밀한 결정상태인 hydroxyapatite $\left[\mathrm{Ca}_{5}\left(\mathrm{PO}_{4}\right)_{3} \mathrm{OH}\right]$ 로 존재한다. 분자량이 작은 유기산은 hydroxyapatite와 상호작용하여 칼슘과 인을 용 출시키며, 유기산은 구조적 특성(mono-, di-, tricarboxylic acid) 에 따라 hydroxyapatite에 화학적으로 흡착되거나 전하에 의하 여 결합되는 것으로 보고되었다(Hannig 등, 2005; Yoshida 등, 2001). 특히 유기산의 carboxyl기가 hydroxyapatite의 인산기와 대체된다는 보고(Yoshida 등, 2001)와 tricarboxylic acid인 구연 산이 dicarboxylic acid인 malic acid보다 hydroxyapatite로부터 인을 용출시키는 정도가 우수함(Wei 등, 2011)을 고려하면 유 기산의 칼슘과 인에 대한 용출 정도의 차이는 유기산 구조의 차이에 기인하는 것으로 사료되었다. 본 연구에서도 구연산은 사골로부터 칼슘과 인의 용출을, 초산은 칼슘의 용출을 선택적 으로 촉진시켰다. 이러한 차이는 구연산과 초산의 구조적인 차 이에 기인하는 것으로 Wei 등(2011)의 보고와 일치하는 경향이 었으며, 추출액에 초산을 $0.01 \sim 0.8 \%$ 첨가한 결과(Park과 Lee $1983)$ 와 곡물식초를 $0.5 \sim 2 \%$ 첨가한 결과 $(\operatorname{Kim} 2002)$ 와 잘 일 치하였다. 따라서 칼슘을 선택적으로 용출시키는 초산에 구연산 을 혼합하여 추출액으로 사용하면 사골 추출물에서 칼슘과 인 비율은 조절할 수 있을 것으로 판단되었다.

칼슘과 인의 용출에 대한 초산과 구연산의 혼합효과를 조사 하였다. 신맛이 강하면 관능적인 선호도가 낮으므로(Kim 2002), $0.2 \%$ 초산용액에 구연산을 $0,0.1,0.2 \%$ 로 각각 첨가한 3 종의 추출액을 준비하여 동일한 방법으로 사골 추출물을 제조하였다. 각 조건에서 칼슘과 인의 용출량은 Table 1 과 같다. 초산 0.2 $\%$ 추출액에 구연산을 첨가하면 칼슘과 인의 용출량은 구연산 농도에 비례하여 증가하였다. 초산 $0.2 \%$ 와 구연산 $0.1 \%$ 혼합 조건의 용출량을 초산 $0.2 \%$ 의 결과와 비교하면 칼슘의 용출량 은 $26.89 \mathrm{mg}$ 에서 $34.22 \mathrm{mg}$ 으로 약 $30 \%$ 증가하였으나 인의 용 출량은 $3.57 \mathrm{mg}$ 에서 $18.45 \mathrm{mg}$ 으로 $400 \%$ 이상 증가하였으며, 칼슘과 인의 비율은 7.53 에서 칼슘 흡수에 적합한 1.85 로 크게 개선되었다. 또한 구연산 사용량을 $0.2 \%$ 로 높인 조건에서 인 용출량의 급격한 증가 $(33.19 \mathrm{mg})$ 는 Fig. $1 \mathrm{~A}$ 에 나타난 구연산의 칼슘과 인의 용출특성에 기인하는 것으로 판단되었다. 또한 초 산과 구연산을 혼합하여 제조한 사골 추출물에서 칼슘과 인의 
Table 1 Combination effect of acetic acid and citric acid on calcium and phosphorus extraction from beef shank bone

\begin{tabular}{ccccc}
\hline $\begin{array}{c}\text { Acetic acid } \\
(\%)\end{array}$ & $\begin{array}{c}\text { Citric acid } \\
(\%)\end{array}$ & $\begin{array}{c}\text { Calcium } \\
\text { content (A) } \\
(\mathrm{mg} / 100 \mathrm{~g} \text { bone })\end{array}$ & $\begin{array}{c}\text { Phosphorus } \\
\text { content (B) } \\
(\mathrm{mg} / 100 \mathrm{~g} \text { bone })\end{array}$ & A/B \\
\hline \multirow{2}{*}{0.2} & 0 & $26.89 \pm 0.096$ & $3.57 \pm 0.46$ & 7.53 \\
& 0.1 & $34.22 \pm 0.59$ & $18.45 \pm 0.74$ & 1.85 \\
& 0.2 & $38.08 \pm 0.28$ & $33.19 \pm 0.52$ & 1.14 \\
\hline
\end{tabular}

Table 2 Sensory evaluation results of beef shank bone extracts prepared with different extraction solutions

\begin{tabular}{ccccc}
\hline Solution & Color & Taste & Flavor & $\begin{array}{c}\text { Overall } \\
\text { acceptability }\end{array}$ \\
\hline DW & $3.75 \pm 0.97^{\mathrm{a}}$ & $3.17 \pm 0.94^{\mathrm{b}}$ & $3.17 \pm 0.83^{\mathrm{a}}$ & $3.33 \pm 0.49^{\mathrm{b}}$ \\
$\begin{array}{c}\text { Acetic acid } 0.2 \% \\
\text { Acetic acid 0.2\% } \\
+\end{array}$ & $3.83 \pm 0.72^{\mathrm{a}}$ & $3.42 \pm 0.90^{\mathrm{b}}$ & $3.00 \pm 0.85^{\mathrm{a}}$ & $3.75 \pm 0.87^{\mathrm{a}, \mathrm{b}}$ \\
$\begin{array}{c}\text { citric acid 0.1\% } \\
\text { (3.33 }\end{array}$ & & & & \\
\hline
\end{tabular}

${ }^{1)}$ Data are means $\pm \mathrm{SD}(n=12)$

${ }^{2)}$ Different superscripts within column indicate significant difference $(p<0.05)$

비율은 1.14 1.85로 칼슘흡수에 적합한 비율을 유지하였다. 사 골 $100 \mathrm{~g}$ 당 칼슘과 인의 함량이 $37.61 \mathrm{~g}$ 과 $658.92 \mathrm{mg}$ 이라는 보 고(Seol과 Jang 1990)를 고려하면, 본 연구에서 초산과 구연산 을 혼합한 경우 칼슘의 용출률은 $0.09 \sim 0.10 \%$, 인은 $2.80 \sim 5.04$ $\%$ 이었다. 이는 칼슘 용출률 $0.02 \sim 0.05 \%$, 인 용출률 $0.2 \sim 0.7 \%$ 이라는 기존의 결과(Seol과 Jang 1990)보다 크게 향상된 결과 이다. 그러나 산성조미료를 첨가하여 제조한 사골 추출물의 경 우 신맛으로 인하여 관능적인 선호도가 감소하므로(Kim 2002), 칼슘 흡수에 적합한 칼슘과 인의 비율을 유지하면서 구연산의 사용량이 적은 $0.2 \%$ 초산 $+0.1 \%$ 구연산 조건이 적합하였다. 상품화하였을 경우 초산과 구연산의 혼합 효과를 비교하기 위 하여 사골 $5.0 \mathrm{~kg}$ 과 $0.2 \%$ 초산 $+0.1 \%$ 구연산 조건의 추출액 $15 \mathrm{~L}$ 를 사용하여 추출한 후 농축, 소금첨가, 유화 과정을 거쳐 서 식품첨가물로 판매되는 사골 추출물의 사양(고형분 $58 \mathrm{brix}$, $\mathrm{NaCl} 12 \%$, 조지방 $16 \%$ )에 맞추어 사골 추출물 시제품을 제 조하고 칼슘과 인의 함량을 조사하였다. 증류수와 $0.2 \%$ 초산 을 각각 사용하여 동일하게 제조한 사골 추출물 시제품과 비교 하였다. 증류수, $0.2 \%$ 초산, $0.2 \%$ 초산 $+0.1 \%$ 구연산을 사용 한 시제품의 칼슘 함량은 각각 $63.1,263.6,580.8 \mathrm{ppm}$,인 함량 은 $104.3,79.1,318.2 \mathrm{ppm}$ 으로 칼슘과 인의 비율은 $0.60,3.33$, 1.83 으로 계산되었다. 시제품에서도 $0.2 \%$ 초산 $+0.1 \%$ 구연산을 사용하면 증류수에 비하여 칼슘 함량은 9배 이상, 인 함량은 3 배 이상 증가하였으며, 칼슘과 인의 비율도 칼슘 흡수에 적합 한 1.83 으로 개선되어 $0.2 \%$ 초산 $+0.1 \%$ 구연산의 조건은 사골 추출물의 무기질 함량 향상과 조성 개선에 매우 효과적인 것으 로 나타났다. 또한 증류수, $0.2 \%$ 초산, $0.2 \%$ 초산 $+0.1 \%$ 구연 산을 사용하여 제조한 시제품의 관능적인 특성을 조사하였다. 그 결과(Table 2), 색과 향 항목은 시료간에 통계적으로는 차이 가 나타나지 않았으나 $0.2 \%$ 초산 $+0.1 \%$ 구연산을 사용한 시료 가 색은 가장 낮은 값을, 향은 가장 높은 값을 보였다. 그러나 맛과 전체적인 기호도 항목에서는 $0.2 \%$ 초산 $+0.1 \%$ 구연산을
첨가하여 제조한 시료가 매우 높은 점수를 나타내어 증류수와 $0.2 \%$ 초산을 사용한 시료와 통계적으로도 유의미한 차이를 보 였다. 본 연구의 결과는 초산을 첨가하여 제조한 사골 추출물 에서 초산 $0.1 \%$ 이상에서는 신맛으로 인한 맛의 변화가 우려 되며(Park과 Lee 1983) 산성 조미료를 첨가한 사골 추출물보다 대조군이 높은 기호도를 보인 결과 $(\operatorname{Kim} 2002)$ 와 상이하였다. 이는 추출 방법의 차이(상압 추출과 가압 추출)에 기인하는 것 으로 사료되었다. $0.2 \%$ 초산 $+0.1 \%$ 구연산을 첨가하여 제조한 시제품의 조단백 함량이 증류수로 제조한 시료보다 높았다. 이 상의 결과는 $0.2 \%$ 초산 $+0.1 \%$ 구연산의 사용은 사골 추출물의 무기질 함량 향상과 조성 개선, 관능 향상을 통하여 사골 추출 물의 품질 향상에 매우 효과적인 방법임을 시사한다.

\section{초 록}

사골로부터 칼슘과 인의 용출량을 증가시킴과 동시에 칼슘의 흡 수에 효과적인 비율로 칼슘과 인의 함량을 조절하기 위하여 초 산과 구연산의 혼합효과를 조사하였다. 사골에 구연산과 초산을 각각 첨가하여 추출물을 제조한 결과, 구연산은 사골로부터 칼 슘과 인을 유사하게 용출시키나, 초산은 인보다 칼슘을 선택적 으로 용출시켰다. 초산 $0.2 \%$ 와 구연산 $0.1 \%$ 를 혼합하여 제조 한 추출물은 초산 $0.2 \%$ 의 결과에 비하여 칼슘의 용출량은 약 $30 \%(26.89 \rightarrow 34.22 \mathrm{mg})$ 증가하였으나 인의 용출량은 약 $400 \%$ $(3.57 \rightarrow 18.45 \mathrm{mg})$ 증가하였으며, 칼슘과 인의 비율은 7.53 에서 1.85 로 크게 개선되었다. 관능평가에서 맛과 전체적인 기호도는 $0.2 \%$ 초산 $+0.1 \%$ 구연산을 첨가하여 제조한 시료가 증류수와 $0.2 \%$ 초산을 사용한 시료보다 우수하였다.

\section{Keywords 구연산 · 사골 추출물 · 초산}

감사의 글 본 연구는 2013년 산학연협력 기술개발사업의 지원을 받아 수행 하였습니다.

\section{References}

Cho EK, Wu HJ, Kim BC, Yoo YM, Lee MY (2014) Effect of bone broyh on the quality of cooked rice as home meal replacement products. Food Eng Prog 18: 87-94

Hannig C, Hamkens A, Becker K, Attin R, Attin T (2005) Erosive effects of different acids on bovine enamel: release of calcium and phosphate in vitro. Arch Oral Biol 50: 541-552

Heinonen JK, Lahti RJ (1981) A new and convenient colorimetric determination of inorganic orthophosphate and its application to the assay of inorganic pyrophosphatase. Anal Biochem 113: 313-317

Karanja N, McCarron DA (1986) Calcium and hypertension. Ann Rev Nutr 6: 475-494

Kim BS, Kim GW, Shim JY (2014) Influence of process conditions on the quality characteristics of beef-bone broth. Food Eng Prog 18: 15-19

Kim JH, Cho SH, Seong PN, Hah KH, Yun YK, Lim DG, Park BY, Lee JM, Kim DH, Ahn CN (2008) Effect of different maturity scores and number of extractions on the sensory traits of water extract from Hanwoo shank bones. Korean J Food Sci Ani Resour 28: 45-50

Kim JH, Lee JM, Park BY, Cho SH, Yoo YM, Kim HK, Kim YK (1999) Effect of portion and times of extraction of shsnk bone from Hanwoo 
bull on physicochemical and sensory characteristics of Komtang. Korean J Food Sci Ani Resour 19: 253-259

Kim MS (2002) The effect on nutrition constituent from beef leg bone by acid condiment. Korean J Soc Food Cookery Sci 18: 349-354

Kim MS (2006) The effect on the nutrition value of beef leg and rib bone soup by boiling time. Korean J Food Culture 21: 161-165

Morgan BR, Artiss JD, Zak B (1993) Calcium determination in serum with stable alkaline arsenazo III and triglyceride clearing. Clin Chem 39: 1608-1612

Park DY, Lee YS (1982) An experiment in extracting efficient nutrients from sagol bone stock. Korean J Nutr Food 11: 47-52

Park DY, Lee YS (1983) The effect of acid and alkali treatment on extracting nutrients from beef bone. Korean J Food Nutr 12: 146-149

Park YH, Park SH, Lee JH, Jo JS (2003) Effects of beef bone extracts on quality of baeck Kimchi. Korean J Soc Food Cookery Sci 19: 188-194

Seol MY, Jang MS (1990) A study on mineral contents in sagol bone stock. Korean J Soc Food Sci 6: 21-26

Wei W, Zhang X, Cui J, Wei Z (2011) Interaction between low molecular weight organic acids and hydroxyapatite with different degrees of crystallinity. Colloids and Surfaces A: Physicochem Eng Aspects 392: 67-75

Yoon GS, Lee BS, Park KH (2009) Effects of the water extract of beef shank bones on the physical and sensory characteristics of cooked rice for Jeonju Bibimbap. J East Asian Soc Dietary Life 19: 1018-1024

Yoshida Y, Van Meerbeek B, Nakayama Y, Yoshioka M, Snauwaert J, Abe Y, Lambrechts P, Vanherle G, Okazaki M (2001) Adhesion to and decalcification of hydroxyapatite by carboxylic acids. J Dental Res 80: 1565-1569 